\title{
STUDENTS' PERSPECTIVE \\ ON KETRAMPILAN WAJIB BAHASA INGGRIS \\ IN UNIVERSITAS MURIA KUDUS
}

\author{
Nuraeningsih \\ Universitas Muria Kudus
}

\begin{abstract}
Due to globalization, the need of English mastery is getting higher. Therefore, it is very important for students to master the international language in order to survive in the global competition. To prepare its alumni with good English competence Universitas Muria Kudusrequires all students to pursue Ketrampilan Wajib Bahasa Inggris (English Compulsory Skill) with 0 SKS. This policy has been ruled since 2001 and organized by Language Center of Universitas Muria Kudus. To know whether the program runs effectively, at the end of each semester, there is an evaluation conducted by the instructors along with the head of the Language Center. However, it does not involve the students. Therefore, it is worthy to investigate students' responses and opinions of the class. This study aims at describing students' perceptions on the learning process of Ketrampilan Wajib Bahasa Inggris in the academic semester of 2014/2015. To achieve the above objectives, this study was conducted by survey. Questionnaires were distributed to 98 students who were selected randomly, out of 498 students joining the class in the academic year 2014/2015. The results of data analysis shows that the learning process of Ketrampilan Wajib Bahasa Inggris class in odd semester academic year 2014/2015 ran well. This is shown from the learning strategies, learning media, learning materials, student interests, students discipline in joining the English course and student mastery were classified as good. Some improvements need to be done so that the quality of learnihng can be improved due to satisfactory service of Language Center.
\end{abstract}

Keywords: Students' Perspective, Ketrampilan Wajib Bahasa Inggris.

\section{INTRODUCTION}

Ketrampilan Wajib Bahasa Inggris (English compulsory class) is an obligatory course which all students of Universitas Muria Kudus must enroll, although it has zero credit. This policy has been ruled since 2001 and implemented by Language Center. It is due to the importance of English mastery in work place.

Since in the early 2000, this policy has developed based on actual needs. Initially Ketrampilan Wajib Bahasa Inggris was taught through TOEIC (Test of English for International Communication). Several years later the policy was evaluated and changed into TOEFL (Test of English as a Foreign Language) test. This change was due to several factors, as the globalization of the country -the world's countries, so we must follow the mastery of the global language reflected through the TOEFL certificate and TOEFL has a higher flexibility because it is 
more accepted by society not only in the workplace but also for academic purposes.

As a compulsory subject that must be enrolled by all students of Universitas Muria Kudus, it results in several consequences. The course participants come from all majors in UMK with different background of English. This yields a diverse learning outcome. Moreover there is no system that separates students who come from English Education Departmentandthose whose majors are non English Education Department. This makes the teaching learning process of the course is more challenging.

At the end of each lesson, Language Center of UMK held an internal evaluation based on the learning result with the lecturers, but has not involved the students. The evalhuation only includes passive English skills (TOEFL score) measurement only. Language Center then added speaking materials to build oral communication skills. However, there was no valid data that describes the evaluation of learning from users (students).

From the above explanation, the writer felt that it is necessary to conduct a research to uncover the existing problems as well as find a solution. The results of this study can provide an overview of the learning process of English Compulsory Skill course that was conducted at Universitas Muria Kudus. In addition, the findings can be input to the institution to improve the learning process of the course at the college.

\section{KETRAMPILAN WAJIB BAHASA INGGRIS}

English is an international language that is used to communicate with all people in the worlhhd in this globalization era. To be able to speak English well, effective learningh process is necessarily conducted. Universitas Muria Kudus is very concerned about the graduates' qualification to win global competition by obliging all students to acquire it in good level. Ketrampilan Wajib Bahasa Inggris is enrolled by students at least when they are at semester five. During the period of its implementation, some changes are made by the Language Center of Universitas Muria Kudus according to graduates' working needs and academic purpose. Initially, the class material was TOEIC (Test of English as an International Communication), then replaced with TOEFL PBT. One year later it was replaced by TOEFL iBT. However, the source and audio materialswere still very limited.Therefore, it was changedinto TOEFL PBT and it is still going on up to now.

\section{Teaching Methods}

To achieve learning purpose, teachers should use effective teaching methods. This effectiveness is generally determined by the characteristics of the method which match with the material features. Therefore, teachers should select appropriate teaching hmethods. There are several approaches that can be used in the process of langhuage teaching. Yulie (2006: 165) says that there are three language approaches that can be used in the process of language learning, including: 
1. The Grammar ITrahnslation Method

This approach is the firstly known approach in learning English. This approach more emphasizes on vocabulary mastery and the use of grammar. The use of word-to-word or sentence translation into mother tongue commonly occurs to understand a text.

2. Audiolingual Method

Method approach is an approach that emphasizes more on spoken language mastery. This approach trains learners to get used to the use of language that is heard so that the learner can imitate the target language without having to think about the pattern of language structure first.

3. Communicative Approach Audiolingual

Communicative Approach is a language learning approach that emphasizes on the use of language functions when communicating.

In reality, teaching TOEFL preparation class by using communicative approach may develop into some similar ones:

a. Interactive Approach

Interactive Approach is an approach where teachers build a reliable interaction with learnersthrough discussion, question and answer and others. This approach emphasizes the interaction process so that learner ability can be identified through the activityconducted during the class.

b. Practical Approach

It is an approach involving the learners to participate in the process of language mastery. Several practical activities are created to engage them and it is supported by the use of teaching media when the learning process occurs. The activation of language knowledge and language usage will help them in succeeding TOEFL test.

c. Psychological approach:

It is an approach which treats learners as individual human being having different language ability. Every student has his/her own characteristics, therefore teachers should be able to identify the problem faced in learning process. This approach more emphasizes on language mastery based on the varied learners' competence in learning the language. In the TOEFL preparation class, a psychological approach can encourage a learner to try to solve a problem when experiencing difficulty in solving various types of TOEFL questions.

Those approaches are some examples of learning approaches that can be used for to teach TOEFL covering listening comprehension, structure and written expression, reading comprehension, writing and speaking.

\section{Teaching Material}

TOEFL is a tool used to measure English proficiency for people who do not speak English in their daily communication. Based on the way in conducting the test, there are two kinds of TOEFL, i.e.: TOEFL iBT (internet Based Test) and TOEFL PBT (Paper Based Test). Due to the limited facility, UMK still uses the conventional way TOEFL test. In other words, it utilizes TEOFL PBT. The 
material consists of listening comprehension, structure and written expression, and reading comprehension. Listening comprehension is the first part of the TOEFL test. This section measures students' competency to understand the text provided through audio. The Listening comprehension test consists of three parts: part A (short conversation), part conversation (longer conversation) and part $\mathrm{C}$ (longer talk / presentation / monolog).

Considering the higher need of English mastery, in odd semester of the 2014/2015 academic year Language Center added speaking as one element of the teaching material. However, it does not directly cover the speaking section of TOEFL. The materials involve basic daily conversation only. Therefore, after participating in this Compulsory Skill, students are expected not only to master receptive English skills but also to master the ability to speak English actively.

\section{Teaching Media}

To make the TOEFL preparation class runs well, the use of media cannot be neglected. The media used are audio and visual. Audio is a sound recording that contains native speaker conversations. Audio is used to explain listening comprehension and some speaking material. The use of handouts as instructional aids is really helpful for students to have independent study. It contains TOEFL material which cover listening, structure, and reading comprehension. In addition, LCD can be a great tool to visualize teachers' explanation and make students concentrate on the topic discussed.

\section{Class Assessment}

To measure how good students achieve in learning, teachers should hold a test at the end of learning. Brown (2004: 3) states that a test is a method for measuring a person's ability, knowledge, and performance in a particular domain. From the explanation above it can be concluded that the test is a tool that can be used to evaluate the results of the learning process. At the end of the semester, a TOEFL test is held by the Language Center of Universitas Muria Kudus, that is attended by all participants of the Ketrampilan Wajib Bahasa Inggris. The TOEFL test lasts approximately 115 minutes with time allocation for each section as follows:

a. Listening section has 35 minutes

b. Structure and written expression has 25 minutes

c. Reading section has 55 minutes

\section{Previous Research}

To support this research, the writer reviewed some relevant studies. Arini (2012) investigated the use of mind mapping to improve the TOEFL score. She tested the mind mapping technique to solve students' difficulty in doing TOEFL test. Her research revealed that mind map technique can be used to eliminate students' obstacles to help students succeed the test. 


\section{RESEARCH METHOD}

To get data relevant to the topic, it is necessary to choose the appropriate research design. This research is descriptive. Arikunto (1998: 310) said that "Descriptive research does not need to prove certain hypotheses but only considers what is available about variables," This is relevant with the purpose of this research to get a comprehensive picture of the learning process of Ketrampilan Wajib Bahasa Inggris. A survey was conducted by collecting data directly from respondents, namely students who joined the course in the 2014/2015 academic year. There were 498 students who were grouped into 14 classes with the number of students per class of approximately 35 students. The sample was 98 students who were chosen randomly. The data was collected by distributing two questionnaires; structured and open questionnaires covering the teaching methods, teaching materials, media used, interests and mastery of the material by students who take part in these compulsory skills. Meanwhile, an open statement consists of 2 things, namely the students 'opinion on the Speaking learning being taught and the students' suggestions on KW English.

\section{FINDING AND DISCUSSION}

\section{Finding}

After the data were collected, the finding of Students' Perceptions on the Learning Process of Ketrampilan Wajib Bahasa Inggris, are described as follows:

Table 4.1 Material mastery

\begin{tabular}{lcccccc}
\hline \multicolumn{1}{c}{ Statement } & & \multicolumn{5}{c}{ Response } \\
& & & & \\
\hline & & & Very good & Good & Fair & Bad \\
\hline $\begin{array}{l}\text { Instructors' mastery } \\
\text { material taught }\end{array}$ & of & the & $42,9 \%$ & $51 \%$ & $6,1 \%$ & 0 \\
\hline Total & & & & & & \\
\hline
\end{tabular}

Table 4.1 above shows that according to respondents, the mastery of KW lecturers (instructors) in English is classified as very good at $42.9 \%$, good categories at $51 \%$ and $6.1 \%$ is sufficient. There were no respondents who said that the lecturers are lacked the material taught. The second item about lecturer mastery of teaching material is described in the next table.

Table 4.2

\begin{tabular}{|c|c|c|c|c|}
\hline \multirow[t]{2}{*}{ Statement } & \multicolumn{4}{|c|}{ Response } \\
\hline & Very good & Good & Fair & Bad \\
\hline $\begin{array}{l}\text { Instructors give at least } 3 \\
\text { accurate examples }\end{array}$ & $64,29 \%$ & $22,45 \%$ & $13,26 \%$ & 0 \\
\hline Total & \multicolumn{4}{|c|}{$100 \%$} \\
\hline
\end{tabular}


From the table above, it is found that the percentage of lecturers giving at least 3 accurate examples is $64.29 \%$ of students saying that in giving accurate examples lecturers are very good. There are $22,45 \%$ of students are good at providing accurate examples. While only $13.26 \%$ of students said that the lecturer was quite good in giving accurate examples.

\section{Learning Media}

Table 4.3

\begin{tabular}{lcccc}
\hline \multirow{2}{*}{ Statement } & \multicolumn{4}{c}{ Response } \\
\cline { 2 - 5 } & Very good & Good & Fair & Bad \\
\hline teachers used varied media & $51,5 \%$ & $29,9 \%$ & $16,5 \%$ & $2,1 \%$ \\
\hline Total & \multicolumn{4}{c}{$100 \%$} \\
\hline
\end{tabular}

The results of the questionnaire showed that $51.5 \%$ respondents said teachers used media varied very good, $29.9 \%$ students approved they good use, $16.5 \%$ said fair and $2.1 \%$ respondents claimed bad use of various media as it is described in table 4.3.

\section{Learning Strategies}

\section{The Use of Various Learning Strategies}

To find out the extent to which lecturers apply effective learning strategies, the statement items are divided into 3 , namely the quality of the use of learning strategies, the participation of lecturers to encourage students to actively discuss and provide opportunities for students to ask questions.

Table 4.4

\begin{tabular}{|c|c|c|c|c|}
\hline \multirow[t]{2}{*}{ Statement } & \multicolumn{4}{|c|}{ Response } \\
\hline & Very good & Good & Fair & Bad \\
\hline $\begin{array}{l}\text { teachers use various language } \\
\text { learning strategies }\end{array}$ & $50 \%$ & $21.4 \%$ & $25.5 \%$ & $3.1 \%$ \\
\hline Total & \multicolumn{4}{|c|}{$100 \%$} \\
\hline
\end{tabular}

Based on table 4.4 , it is found that $50 \%$ respondents claimed all teachers use various learning strategies very well, $21.4 \%$ said that the teachers use learning strategies well, $25.5 \%$ reported that the use of varied learning strategies is sufficient and $3.1 \%$ of students state that the teachers are bad in using variety of learning strategies. 
PROMINENT Journal, Volume 2, Number 2, July 2019

Encourage Students to be Active in Discussions

Table 4.5. Giving opportunities to be actively engaged

\begin{tabular}{lcccc}
\hline \multirow{2}{*}{ Statement } & \multicolumn{3}{c}{ Response } \\
\cline { 2 - 5 } & Very good & Good & Fair & Bad \\
\hline $\begin{array}{l}\text { Teachers provide opportunities for } \\
\text { students actively engaged in class } \\
\text { discussion }\end{array}$ & $23.5 \%$ & $51 \%$ & $23.5 \%$ & $2 \%$ \\
\hline Total & & & \\
\hline
\end{tabular}

From the table above it can be seen that $23.5 \%$ respondents state that KW Bahasa Inggris teachers are very good at providing opportunities for students to actively discuss. $51 \%$ are good, $23,5 \%$ are sufficient and $2 \%$ are lacking in encouraging students to actively discuss.

Give an Opportunity to Ask Questions

Table 4.6. Giving opportunities for asking questions

\begin{tabular}{lccccc}
\hline \multicolumn{2}{c}{ Statement } & \multicolumn{4}{c}{ Response } \\
\cline { 2 - 6 } & & Very good & Good & Fair & Bad \\
\hline teachers give students & the & $36.8 \%$ & $52 \%$ & $11.2 \%$ & 0 \\
opportunity to ask questions & & & \multicolumn{5}{c}{$100 \%$} \\
\hline Total & & & \\
\hline
\end{tabular}

In the process of learning English in KW Bahasa Inggris class, the teachers encourage students to actively ask questions. This is evidenced by the finding off $36.8 \%$ respondents said that $\mathrm{KW}$ Bahasa Inggris teachers are very good at giving opportunities to ask questions, $52 \%$ are good, and $11.2 \%$ are sufficient in giving opportunities to ask questions.

\section{Tutor Discipline}

Table 4.7. Tutor's discipline

\begin{tabular}{lcccc}
\hline \multicolumn{1}{c}{ Statement } & \multicolumn{3}{c}{ Response } \\
\cline { 2 - 5 } & Very good & Good & Fair & Bad \\
\hline $\begin{array}{l}\text { Teachers start and finish the class } \\
\text { on time }\end{array}$ & $34.69 \%$ & $48.98 \%$ & $12.25 \%$ & $4.08 \%$ \\
\hline Total & \multicolumn{4}{c}{$100 \%$} \\
\hline
\end{tabular}

In terms of the teachers' discipline in starting and ending the class, the finding revealed that $34.69 \%$ students claimed that KW Bahasa Inggris teachers are very good in lecturing time management, $48.98 \%$ of respondents declared that they have good discipline, $12,25 \%$ stated that the teachers were sufficient in discipline and there were $4.08 \%$ of lecturers who lacked discipline in start and end college on time. 
PROMINENT Journal, Volume 2, Number 2, July 2019

Students' Interest in Ketrampilan Wajib Bahasa Inggris

Tabel 4.8 Students' Interest in KW Bahasa Inggris

\begin{tabular}{llccc}
\hline \multirow{2}{*}{ Statement } & \multicolumn{4}{c}{ Response } \\
\cline { 2 - 5 } & Very high & High & Fair & Low \\
\hline $\begin{array}{l}\text { My interest in learning KW } \\
\text { Bahasa Inggris is .... }\end{array}$ & $21,43 \%$ & $52,04 \%$ & $24,49 \%$ & $2,04 \%$ \\
\hline Total & \multicolumn{4}{c}{$100 \%$} \\
\hline
\end{tabular}

The next question is student interest in KW Bahasa Inggris. After analyzing the questionnaire, it was found that $21.43 \%$ of respondents had a very high interest in learning KW Bahasa Inggris, while 52.04\% of respondents claimed to have high interest, $24.49 \%$ felt quite interested and $2.04 \%$ felt less interested in learning English.

Students' Discipline

Table 4.8. Students' Discipline

\begin{tabular}{lcccc}
\hline \multirow{2}{*}{ Statement } & \multicolumn{3}{c}{ Response } \\
\cline { 2 - 5 } & Very good & Good & Fair & Bad \\
\hline $\begin{array}{l}\text { My discipline in joining KW } \\
\text { Bahasa Inggris }\end{array}$ & $56,25 \%$ & $28,13 \%$ & $13,54 \%$ & $2,08 \%$ \\
\hline Total & \multicolumn{4}{c}{$100 \%$} \\
\hline
\end{tabular}

Because the learning process can take place if there are students, the research team also analyzed student discipline in attending the KW English class. In table 4.9 , it can be seen that $56.25 \%$ of respondents claimed they were very disciplined in attending KW English courses, $28.13 \%$ of respondents felt disciplined, $13.54 \%$ were quite disciplined and as many as $2.08 \%$ claimed to lack discipline in attending KW lectures English.

a. Students' English mastery

Table 4.9. Students' English mastery

\begin{tabular}{lccccc}
\hline \multicolumn{2}{c}{ Statement } & \multicolumn{4}{c}{ Response } \\
\cline { 3 - 5 } & Very good & Good & Fair & Poor \\
\hline $\begin{array}{l}\text { My understanding } \\
\text { mastery is ..... }\end{array}$ & $8,2 \%$ & $46,9 \%$ & $39,8 \%$ & $5,1 \%$ \\
\hline Total material & \multicolumn{4}{c}{$100 \%$} \\
\hline
\end{tabular}

The last question in the closed questions section is about students' mastery of the material that has been taught. From the results of the questionnaire showed that as many as $8.2 \%$ of respondents had very good English mastery of the class. Most respondents (46.9\%) claimed that they master the material well and many of 
them $(39.8 \%)$ reported to have sufficient English mastery. However, there are few students $(5.1 \%)$ who feel that they have poor English mastery.

\section{Students' Opinions about Speaking Materials}

The second part of the questionnaire is the items asking about students' opinions of speaking material. Since the odd semester of the 2014/2015 academic year the KW Bahasa Inggris material does not only cover the TOEFL, but also include speaking skill. Therefore, it is important to find out the students' opinions regarding the new policy. The following data in table 4.11 which shows the importance of English speaking skill. The results showed that $30.61 \%$ of respondents felt speaking is very necessary to teach. The majority of respondents $65,31 \%$ felt it is necessary to learn speaking. While $1,02 \%$ felt less necessary and as much as $3.06 \%$ felt no need to learn speaking material.

Table 4.11. Students' opinion about speaking skill

\begin{tabular}{lcccc}
\hline \multirow{2}{*}{ Statement } & \multicolumn{3}{c}{ Response } \\
\cline { 2 - 4 } & $\begin{array}{c}\text { Very } \\
\text { necessary }\end{array}$ & Necessary & $\begin{array}{c}\text { Less } \\
\text { necessary }\end{array}$ & No need \\
\hline Speaking skill is considered ...... & $8,2 \%$ & $46,9 \%$ & $39,8 \%$ & $5,1 \%$ \\
\hline Total & \multicolumn{4}{c}{$100 \%$} \\
\hline
\end{tabular}

\section{DISCUSSION}

\section{Students' Perceptions of KW Bahasa Inggris Learning Process}

From the results of the questionnaire distributed to respondents, obtained data are described as follows:

\section{Mastery of Materials and Giving Accurate Examples}

Table 4.1 above shows that the lecturer or teachers mastered the teaching material. This can be seen from the percentage of $42.9 \%$ of very good and $51 \%$ of students' good English mastery. Besides, it can also be seen from the data of giving a minimum of three accurate examples in the teaching and learning process. It is found that $64.29 \%$ of very good and $22.45 \%$ of good as described in table 4.2. This shows that the teachers or instructors had great preparation before starting their classes. This preparation involves the class coordination meeting to check the modules, purchasing library materials and revising the modules if it is necessary to do. The Language Center always strives to provide the best service for students. In designing the module, the writer team has adapted English development, particularly TOEFL. Providing books as references has become a routine for the Language Center as an effort to update and enrich the learning materials.

\section{Learning Media}

Table 4.3 showed that teachers make use of varied media very well. This can be seen from the use of available facilities in the language laboratory in the learning process that support teachers and students interact each other in the 
learning process in order to achieve the learning achievement. However, the facilities usage is greatly less than the number of students enrolling this class.

\section{Teaching Strategy}

One of the efforts to succeed the learning process is by applying a good learning strategy. Table 4.4 shows that most teachers have made use of varied teaching strategies. It can be seen from the percentage of $50 \%$ for very good and $21.4 \%$ good. In other words, almost all lecturers do not use one single learning strategies. Varied teaching strategies have a positive impact on students that can encourage students to be active in discussions and the classroom atmosphere becomes more live so that lecturers also give students the opportunity to ask more questions. Table 4.5 shows that teachers provide great opportunities for students to actively engage in discussion by $23.5 \%$, and good by $51 \%$ and enough by $23.5 \%$. Table 4.6 which shows that all lecturers gave students the opportunity to ask questions with a very good percentage of $36.8 \%$ and good $52 \%$ of the rest was sufficient.

\section{Discipline of Tteachers}

Table 4.7. shows the teachers in starting and ending lectures. Based on the results of the study, the discipline of lecturers was considered good at $48.9 \%$ and very good at $34.69 \%$. In other words, lecturers have discipline in starting and ending classes.

\section{Students' Interest in Ketrampilan Wajib Bahasa Inggris}

From the results of table 4.8 , it is found that $21.43 \%$ of respondents said that they have very high interest in KW Bahasa Inggris, 52.04\% claimed that they have high interest and the rest is sufficient. However, there is $2.04 \%$ students who have low interest in learning this subject. Enrolling this course is compulsory for all students because it contributes a lot to their English skill.

\section{Students' Discipline}

Discipline is something that can be used to measure the effectiveness of an activity. Table 4.9 shows that $56 \%$ of respondents claimed they were very disciplined in attending the KW Bahasa Inggris class, while $28.13 \%$ of respondents felt disciplined, and $13.54 \%$ were quite disciplined. However, $2.08 \%$ students claimed that they are less disciplined in attending a KW Bahasa Inggris class. The varied response reflects the different range of respondents' motivation in learning English.

\section{Students' mastery of the teaching material}

Table 4.10 describes the mastery of students on the material that has been taught. The finding shows that $8.2 \%$ of respondents felt that they achieved very good mastery, while other respondents claimed to have good mastery (46.9\%) and some other students (39.8\%) reported to have sufficient mastery. There is $5.1 \%$ who said that they have poor mastery of TOEFL. This big number of sufficient and poor mastery seems a sign that almost half of students need to struggle in understanding the TOEFL materials and need teachers' help to achieve the learning objectives. 


\section{Students' Opinions about Speaking Materials}

Based on the finding in table 4.11, it can be seen that most students regard the necessity to acquire speaking skill. It means that most students agree to this new policy to put speaking as supplementary material in TOEFL. This result can be an important consideration to continue the policy for the Language Center as the management of the KW Bahasa Inggris class.

\section{CONCLUSION AND SUGGESTION}

Based on the findings of this study, it can be concluded that the process of learning Ketrampilan Wajib Bahasa Inggris in odd semester 2014/2015 academic year runs well based on aspects of learning strategies, teaching materials, learning media, students' interest in English, students' discipline and students' mastery of the material being taught. In addition, speaking material is extremely necessary to teach to students. Therefore, it becomes a consideration to continue to this policy in the coming academic years.

Some suggestions are proposed as follows:

1. Language Center as a unit that provides language services needs to improve the quality of learning both from learning strategies, teaching materials, media as well as the competence of KW English lecturers. This can be done through various means, such as instructor development by training them to improve their English proficiency

2. It is necessary to implement one English day within the university as a way to improve English skill of lecturers, staff and students, as an effort to motivate students.

3. Lecturer mastery of the material taught needs to be supplemented by increasing the number of available literature.

4. Speaking \& listening needs to get the attention of the lecturers so that students have the ability to speak English passively and actively in accordance with the needs of employment.

5. Language Center should have English day where all teachers and students must speak in English in a certain day.

\section{REFERENCES}

Arikunto, Suharsimi. (1998). Metodologi Penelitian. Jakarta: PT Rineka Cipta

Arini, Yusti. (2012). Peningkatan Penguasaan TOEFL Melalui Teknik Mind Map. Tapis Jurnal Penelitian Ilmiah No.1 Volume 12

Loviyenty, Leffi. Upaya Peningkatan Kompetensi Bahasa Inggris Mahasiswa Program Studi Pendidikan Agama Islam (PAI) STAIN Curup dan Relevansinya terhadap TOEFL ScoreSebagai Prasarat Wisuda. IAIN Curup: Jurnal Pendidikan Islam, Vol. 3 no.2, 2018. 
PROMINENT Journal, Volume 2, Number 2, July 2019

Mills, Geoffrey. (2000). Action Research A Guide for Teacher Researcher. New York: Southern Oregon University

Prasetyo, Bambang \&Jannah, Miftahul. (2005). Metode Penelitian Kuantitatif Teori dan Aplikasi.Bandung: PT Rosdakarya.

Rizky Dermawan, 2007, Penerapan Total Quality Management (TQM) di Perguruan Tinggi (Menuju Perguruan Tinggi yang Berkualitas), Bunga Rampai Strategic, Manajemen Bisnis berbasis Hasil Penelitian, Cetakan Kesatu, April 2007, Alfabeta, Bandung, p. 45 - 57.

Rusdarti, 2004, Pengaruh Kualitas Pelayanan dan Nilai Pelayanan terhadap Loyalitas Nasabah pada Bank BPD Jawa Tengah Cabang Semarang, Jurnal Bisnis Strategi, Vol. 13/ Juli/ 2004, p. 54 - 65.

Sugiyono, 2004, Metode Penelitian Bisnis, Alfabeta, Bandung.

Samosir, Zurni Zahara, 2005, Pengaruh Kualitas Pelayanan terhadap Kepuasan Mahasiswa Menggunakan Perpustakaan USU, Pustaha: Jurnal Studi Perpustakaan dan Informasi, Vol. 1, no. 1, Juni 2005, 